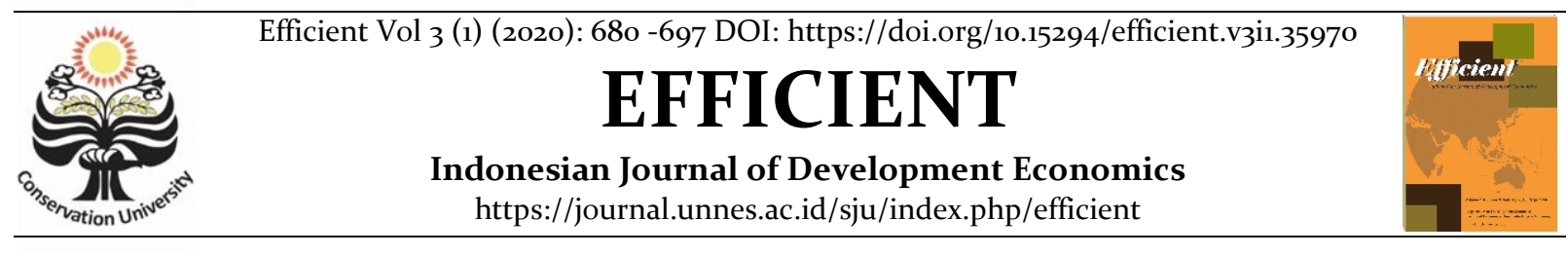

\title{
Pengaruh Program Bos terhadap Keputusan Anak Putus Sekolah
}

\author{
Pramudina Rahmawati ${ }^{\bowtie}$ \\ Jurusan Ekonomi Pembangunan, Fakultas Ekonomi, Universitas Negeri Semarang \\ Permalink/DOI: https://doi.org/10.15294/efficient.v3i1.35970 \\ Received: July 2019 ; Accepted: October 2019 ; Published: January 2020

\begin{abstract}
This study aims to analyze the influence of the BOS Program on junior high school dropout decisions in Purworejo Regency and analyze individual, family and school characteristics of junior high school dropout decisions in Purworejo Regency. This type of research is quantitative. The population used in this study were all junior high school children in Purworejo Regency with 24,827 students graduating from junior high school and 30 students dropping out of school. Data analysis method used in this study is binary logit regression. The results in this study indicate that the BOS Program has no significant effect on the decision of school dropouts because BOS funds cannot cover all school operational costs so that many school fees are charged to parents and there are other factors that cause children's decision to drop out of school. Individual characteristics in the form of education and health perceptions significantly influence the decision of school dropouts. Family characteristics in the form of the number of siblings, siblings drop out of school, help parents, and academic support of parents significantly influence the decision of children dropping out of school. School characteristics such as problems with teachers, problems with friends, and distance do not have a significant effect, while school dropouts have a statistically significant effect on the decisions of dropouts.
\end{abstract}

\section{Keywords: Education, School Operational Assistance (BOS), dropout}

\begin{abstract}
Abstrak
Penelitian ini bertujuan untuk menganalisis pengaruh Program BOS terhadap keputusan anak putus sekolah tingkat SMP di Kabupaten Purworejo dan menganalisis karakteristik individu, keluarga dan sekolah terhadap keputusan anak putus sekolah tingkat SMP di Kabupaten Purworejo. Jenis penelitian ini adalah kuantitatif. Populasi yang digunakan dalam penelitian ini adalah seluruh anak sekolah menengah pertama di Kabupaten Purworejo dengan anak yang lulus sekolah menengah pertama sejumlah 24.827 siswa dan anak putus sekolah sebanyak 30 siswa. Metode analisis data yang digunakan dalam penelitian ini adalah regresi binary logit. Hasil dalam penelitian ini menunjukkan bahwa Program BOS tidak berpengaruh signifikan terhadap keputusan anak putus sekolah karena dana BOS tidak dapat menutup semua biaya operasional sekolah sehingga banyak biaya sekolah yang dibebankan kepada orang tua siswa serta terdapatnya faktor lain yang menyebabkan keputusan anak untuk putus sekolah. Karakteristik individu berupa persepsi pendidikan dan kesehatan berpengaruh signifikan terhadap keputusan anak putus sekolah. Karakteristik keluarga berupa jumlah saudara, saudara kandung putus sekolah, membantu orang tua, dan dukungan akademik orang tua berpengaruh signifkan terhadap keputusan anak putus sekolah. Karakteristik sekolah berupa masalah dengan guru, masalah dengan teman, dan jarak tidak berpengaruh signifikan, sedangkan teman putus sekolah berpengaruh signifikan secara statistik terhadap keputusan anak putus sekolah.
\end{abstract}

Kata Kunci: Pendidikan, Program BOS, Anak Putus Sekolah

How to Cite: Rahmawati, P. (2020). Pengaruh Program Bos terhadap Keputusan Anak Putus Sekolah. Efficient: Indonesian Journal of Development Economics, 3(1), 680-697. https://doi.org/10.15294/efficient.v3i1.35970

(C) 2019 Semarang State University. All rights reserved

\footnotetext{
Alamat Korespondensi :

Alamat: Gedung L2 Lantai 2 FE Unnes

Kampus Sekaran, Gunungpati, Semarang, 50229

E-mail : pramudina97@gmail.com
}

ISSN 2655-6197 


\section{PENDAHULUAN}

Pendidikan merupakan penggerak utama dalam pembangunan nasional (Ali, 2009). Selain itu, pendidikan juga mempunyai peran yang sangat penting dalam perkembangan dan kelangsungan hidup bangsa (Badan Pusat Statistik, 2018). Hal ini dikarenakan pendidikan dapat menciptakan masyarakat yang berdaya saing tinggi, khususnya dalam menciptakan sumber daya manusia yang berkualitas dan juga dapat membentuk kemandirian untuk dijadikan bekal dalam menghadapi tangan-tantangan globalisasi di masa depan terutama pada saat Indonesia memasuki era pasar bebas di tahun 2020 (Ali, 2009).

Sumber daya manusia merupakan bentuk investasi yang dilakukan melalui pendidikan (Atmanti, 2005). Investasi ini dikenal dengan istilah human capital, di mana seseorang dapat meningkatkan pendapatannya melalui pendidikan. Semakin seseorang mencapai tingkat pendidikan yang lebih tinggi, maka akan cenderung memiliki perkerjaan dan upah yang lebih baik dibandingkan seseorang yang berpendidikan rendah.

Hasil Susenas Badan Pusat Statistik menunjukkan bahwa pencapaian pendidikan dan partisipasi sekolah di Indonesia rendah. Angka melek huruf penduduk umur 15 tahun ke atas sebesar 95,66\%, angka tersebut masih di bawah target yang ditetapkan dalam Renstra Kemendikbud. Sementara itu, rata-rata lama sekolah penduduk umur 15 tahun ke atas masih mencapai 8,58 tahun atau setara kelas 2 SMP/sederajat. Angka tersebut juga masih di bawah target yang ditetapkan dalam Renstra Kemendikbud.

Salah satu program yang dilaksanakan oleh pemerintah untuk meningkatkan partisipasi sekolah adalah dengan diadakannya program pendidikan gratis pada tingkat dasar dan didukung oleh dana Bantuan Operasional Sekolah (BOS) yang dialokasikan dari Anggaran Pendapatan dan Belanja Negara (APBN). Program BOS pada tingkat pendidikan dasar mulai dilaksanakan pada tahun 2005 dan diberikan kepada sekolahsekolah tingkat SD dan SMP dengan tujuan untuk membebaskan biaya pendidikan bagi siswa yang tidak mampu dan meringankan beban bagi siswa yang lain, agar dapat memperoleh layanan pendidikan dasar yang lebih bermutu sampai tamat dalam rangka pencapaian Program Wajib Belajar Pendidikan Dasar Sembilan Tahun (Kharisma, 2013), seperti yang tertuang dalam Undang-Undang Nomor 20 Tahun 2003 tentang Sistem Pendidikan Nasional pasal 6 ayat (1) yang menyebutkan bahwa setiap warga negara yang berusia 7-15 (tujuh sampai dengan lima belas) tahun wajib mengikuti pendidikan dasar.

Selain pendidikan dasar, pemerintah juga telah mencanangkan program Wajib Belajar 12 Tahun yang merupakan program keberlanjutan dari program Wajib Belajar 9 tahun. Meskipun Wajib Belajar 12 Tahun sudah diberlakukan sejak tahun 2015, akan tetapi Wajib Belajar 9 Tahun merupakan program minimal yang harus dituntaskan terlebih dahulu (Ali, 2009) karena keberhasilan mengikuti pendidikan di sekolah menengah dan perguruan tinggi banyak dipengaruhi oleh keberhasilan dalam mengikuti pendidikan dasar.

Hal tersebut juga telah ditegaskan dalam Peraturan Pemerintah Republik Indonesia Nomor 47 Tahun 2008 Pasal 1 yang menyebutkan bahwa program pendidikan minimal yang harus diikuti warga negara 
Indonesia atas tanggung jawab pemerintah dan pemerintah daerah adalah jenjang pendidikan yang melandasi jenjang pendidikan menengah. Pendidikan yang dimaksudkan disini adalah Sekolah Dasar (SD)/sederajat dan Sekolah Menengah Pertama (SMP)/sederajat.

Penyaluran BOS dilakukan di setiap sekolah jenjang SD, SMP, dan SMA/SMK baik negeri maupun swasta di seluruh provinsi di Indonesia. Pengalokasian besaran dana BOS yang diberikan ke sekolah didasarkan dengan jumlah murid, dengan perhitungan pada tabel 1 dan penyalurannya dilakukan setiap periode 3 (tiga) bulanan, yaitu periode Januari-Maret, April-Juni, Juli-September, dan OktoberDesember.

Tabel 1. Perhitungan Besaran Dana BOS

\begin{tabular}{llll}
\hline Jenjang & \multicolumn{3}{c}{ Alokasi } \\
\hline SD & Rp 800.000,-/ siswa/ tahun \\
SMP & Rp & $1.000 .000,-/$ & siswa/ \\
SMA/SMK & Rp & $1.400 .000,-/$ & siswa/ \\
\hline
\end{tabular}

Sumber: Juknis BOS dalam Permendikbud, 2017

Selain untuk meningkatkan partisipasi sekolah, program BOS juga merupakan salah satu upaya yang dilakukan oleh pemerintah dalam hal pemerataan pendidikan yang mengacu pada perluasan kesempatan bagi seluruh masyarakat, khususnya siswa dari keluarga kurang mampu agar dapat mengakses pendidikan yang berkualitas sehingga diharapkan tidak ada lagi siswa miskin yang putus sekolah karena tidak mampu menjangkau biaya pendidikan. Namun pada kenyataannya, program yang dicanangkan oleh pemerintah tersebut belum sepenuhnya berhasil. Hal ini terlihat dari tingginya angka putus sekolah pada jenjang pendidikan dasar (dalam hal ini SD dan SMP) meskipun program BOS sudah dilaksanakan. Tentunya ini menjadi pertanyaan sekaligus permasalahan baru dalam dunia pendidikan.

Tabel 2. Jumlah Angka Putus Sekolah di Indonesia pada Jenjang Pendidikan Dasar Tahun 2013/2014-2017/2018

\begin{tabular}{lllll}
\hline \multirow{2}{*}{ Tahun } & \multicolumn{2}{c}{ SD } & \multicolumn{2}{c}{ SMP } \\
\cline { 2 - 5 } & Jumlah & $\%$ & Jumla & $\%$ \\
\hline $2013 / 2014$ & 294.045 & 1,11 & 137.43 & 1,41 \\
$2014 / 2015$ & 176.909 & 0,68 & 85.00 & 0,86 \\
$2015 / 2016$ & 68.066 & 0,26 & 51.541 & 0,51 \\
$2016 / 2017$ & 39.213 & 0,15 & 38.70 & 0,38 \\
$2017 / 2018$ & 32.127 & 0,13 & 51.190 & 0,51 \\
Total & 610.360 & 2,33 & 363.8 & 3,67 \\
\hline
\end{tabular}

Sumber: Kementrian Pendidikan dan Kebudayaan, 2018

Tabel 2 menunjukkan perkembangan jumlah angka putus sekolah di Indonesia pada jenjang pendidikan dasar dari tahun ajaran 2013/2014 sampai dengan tahun ajaran 2017/2018. Selama lima tahun terakhir, angka putus sekolah untuk jenjang SD dan SMP selalu mengalami penurunan. Hal tersebut dapat dilihat dari jumlah dan persentase angka putus sekolah setiap tahunnya yang menunjukkan tren menurun, kecuali pada jenjang SMP tahun ajaran 2017/2018. Pada tahun tersebut, angka putus sekolah pada jenjang SMP mengalami kenaikan sebesar 12.488 atau naik 0,13\% dari tahun sebelumnya. Selain itu, meskipun total angka putus sekolah tertinggi terjadi pada jenjang SD, akan tetapi total persentase angka putus sekolah menunjukkan bahwa jenjang SMP lebih tinggi dibandingkan total persentase angka putus sekolah jenjang SD. Hal ini dapat dikatakan bahwa penuntasan wajib belajar pendidikan dasar sembilan tahun dan dukungan 
pemerintah berupa Bantuan Operasional Sekolah (BOS) belum tercapai, khususnya pada tingkat Sekolah Menengah Pertama (SMP).

Tabel 3 menunjukkan lima provinsi yang memiliki angka putus sekolah tertinggi di Pulau Jawa dari tahun 2013/2014 sampai dengan tahun ajaran 2017/2018. Dari tabel tersebut, terlihat bahwa jumlah siswa putus sekolah tertinggi di Pulau Jawa ditempati oleh Provinsi Jawa Barat dengan total 75.674 siswa putus sekolah. Posisi kedua yaitu Provinsi Jawa Timur dengan total 38.307 siswa putus sekolah. Dan posisi ketiga yaitu Provinsi Jawa Tengah dengan total 37.008 siswa putus sekolah.

Tabel 3. Jumlah Siswa Putus Sekolah Jenjang SMP di Pulau Jawa Tahun Ajaran 2013/2014 -2017/2018

\begin{tabular}{lllllll}
\hline Provinsi & $2013 / 2014$ & $2014 / 2015$ & $2015 / 2016$ & $2016 / 2017$ & $2017 / 2018$ & TOTAL \\
\hline DKI Jakarta & 4.951 & 2.716 & 1.377 & 1.080 & 1.757 & 11.881 \\
Jawa Barat & 28.246 & 19.314 & 10.139 & 8.635 & 9.340 & 75.674 \\
Banten & 6.801 & 3.885 & 2.360 & 1.727 & 2.682 & 17.455 \\
Jawa Tengah & 17.884 & 6.194 & 4.366 & 3.673 & 4.891 & 37.008 \\
DI Yogyakarta & 1.709 & 362 & 293 & 239 & 420 & 3.023 \\
Jawa Timur & 13.271 & 8.564 & 4.783 & 4.157 & 7.532 & 38.307 \\
Pulau Jawa & 72.862 & 41.035 & 23.318 & 19.511 & 26.622 & 183.348 \\
\hline
\end{tabular}

Sumber: Kementrian Pendidikan dan Kebudayaan, 2018

Walaupun Provinsi Jawa Tengah menempati posisi ketiga dengan jumlah siswa putus sekolah tertinggi, namun terdapat beberapa indikator yang mencerminkan rendahnya kualitas masyarakat khususnya kualitas pendidikan di Provinsi Jawa Tengah seperti Angka Partisipasi Murni (APM) dan Rata-rata Lama Sekolah yang masih rendah.

Tabel 4 menunjukkan besarnya persentase angka putus sekolah jenjang SMP tahun 2017 di Provinsi Jawa Tengah. Dari 35 Kabupaten/Kota yang ada di Provinsi Jawa Tengah, terdapat beberapa Kabupaten/Kota dengan persentase angka putus sekolah tertinggi yaitu Kabupaten Purworejo, Kabupaten Brebes, Kota Tegal, Kabupaten Wonosobo, dan Kabupaten Wonogiri. Persentase angka putus sekolah tertinggi ditempati oleh Kabupaten Purworejo sebesar 6,98\%. Hal tersebut yang menjadikan alasan perlunya penelitian ini dilakukan di Kabupaten Purworejo.
Menurut Setyadharma (2015), terdapat beberapa faktor yang mempengaruhi keputusan anak putus sekolah, yaitu karakteristik individu. Karakteristik individu didasarkan pada atribut siswa seperti sikap dan perilaku yang dapat dikaitkan dengan keputusan mereka untuk meninggalkan sekolah tanpa ijazah (Witte and Rogge, 2013). Bergeron et al., (2011) menemukan bahwa sikap mendevaluasi pentingnya sekolah secara signifikan berkorelasi dengan kemungkinan putus sekolah. Selain itu, Todaro \& Smith (2006) berpendapat bahwa kesehatan juga berpengaruh dengan produktivitas seseorang dalam meningkatkan sumber daya manusia.

Faktor kedua yang mempengaruhi perilaku putus sekolah yaitu karakteristik keluarga. Anak yang berasal dari orang tua yang berpendidikan rendah dan harapan rendah untuk kesuksesan anak-anak mereka lebih cenderung mengalami putus sekolah (Witte and Rogge, 2013). Kamsihyati dkk., 
(2016) mengatakan bahwa keadaan keluarga membawa pengaruh terhadap pendidikan dan minat sekolah anak. Status sosioekonomi dan banyaknya anggota keluarga juga berkorelasi dengan kemungkinan putus sekolah. Selain itu, temuan menujukkan bahwa membantu orang tua membawa pengaruh dalam belajar anak sehingga apabila waktu belajar anak menjadi terganggu, maka hal tersebut dapat memungkinkan terjadinya putus sekolah. Oleh karena itu, lingkungan yang baik sangat diperlukan dalam keluarga karena keluarga mempunyai peran yang sangat besar untuk perkembangan anak. Tidak adanya saudara kandung yang putus sekolah juga berkorelasi dengan kemungkinan putus sekolah.

Tabel 4. Angka Putus Sekolah jenjang SMP Tertinggi di Kabupaten/Kota Provinsi Jawa Tengah Tahun 2017 (dalam persen)

\begin{tabular}{ll}
\hline Kabupaten/Kota & $\begin{array}{l}\text { Persentase Putus } \\
\text { Sekolah }\end{array}$ \\
\hline Kabupaten Purworejo & 6,98 \\
Kabupaten Wonosobo & 4,99 \\
Kabupaten Wonogiri & 3,80 \\
Kabupaten Brebes & 5,45 \\
Kota Tegal & 5,03 \\
Jawa Tengah & 1,84 \\
\hline
\end{tabular}

Sumber: Badan Pusat Statistik, 2017

Faktor ketiga yang mempengaruhi perilaku putus sekolah yaitu karakteristik sekolah. Di lingkungan sekolah, anak-anak banyak berinteraksi dengan teman dan guru sehingga membutuhkan suasana yang baik. Hubungan baik antara anak dengan teman dan guru di sekolah cenderung menjadikan anak lebih bersemangat untuk bersekolah. Sebaliknya, terjadinya konflik dengan teman di sekolah mengakibatkan anak tidak disukai oleh teman-teman yang lain sehingga menjadikan anak tersebut merasa tidak nyaman berada di sekolah dan akhirnya lebih memilih untuk berhenti sekolah (Kamsihyati dkk., 2016). Menurut Arizona (2013), jarak dari rumah ke sekolah juga memungkinkan terjadinya putus sekolah, terlebih apabila transportasi umum tidak memadai untuk menempuh perjalanan menuju sekolah. Selain itu, lingkungan pergaulan anak juga turut mempengaruhi keputusan anak untuk menyelesaikan sekolah sebelum waktunya, contohnya seperti keberadaan teman putus sekolah di lingkungan pergaulan (Zaenuri et al., 2014).

Faktor keempat adalah kebijakan pemerintah berupa BOS. Menurut Granado et al., (2007) program BOS dapat mendorong lebih banyak anak dari rumah tangga miskin untuk bersekolah. Selain itu, program BOS juga dapat dijadikan instrumen untuk mencegah dan menurunkan angka putus sekolah.

Berdasarkan latar belakang tersebut maka dapat dirumuskan beberapa pertanyaan penelitian. (1) Apa saja karakteristik individu yang mempengaruhi keputusan anak untuk putus sekolah tingkat SMP di Kabupaten Purworejo? (2) Apa saja karakteristik keluarga yang mempengaruhi keputusan anak untuk putus sekolah tingkat SMP di Kabupaten Purworejo? (3) Apa saja karakteristik sekolah yang mempengaruhi keputusan anak untuk putus sekolah tingkat SMP di Kabupaten Purworejo? (4) Bagaimana pengaruh dari Program Bantuan Operasional Sekolah terhadap keputusan anak untuk putus sekolah tingkat SMP di Kabupaten Purworej. Adapun 
tujuan dari penelitian ini adalah untuk mengetahui dan menganalisis: (1) Karakteristik individu yang mempengaruhi keputusan anak untuk putus sekolah tingkat SMP di Kabupaten Purworejo. (2) Karakteristik keluarga yang mempengaruhi keputusan anak untuk putus sekolah tingkat SMP di Kabupaten Purworejo. (3) Karakteristik sekolah yang mempengaruhi keputusan anak untuk putus sekolah tingkat SMP di Kabupaten Purworejo. (4) Pengaruh dari Program Bantuan Operasional Sekolah Sekolah terhadap keputusan anak untuk putus sekolah tingkat SMP di Kabupaten Purworejo.

World Bank mendefinisikan putus sekolah merupakan total laki-laki dan perempuan dalam tingkat sekolah dasar atau menengah pada tahun tertentu yang tidak lagi bersekolah pada tahun ajaran berikutnya. Sedangkan UNESCO mendefiniskan putus sekolah merupakan siswa yang meninggalkan sekolah pada tahun ajaran tertentu.

Beberapa literatur juga menjelaskan definisi putus sekolah seperti Mudyaharjo (2001) yang mengatakan bahwa putus sekolah adalah siswa yang meninggalkan sekolah sebelum menyelesaikan keseluruhan masa belajar yang telah ditetapkan oleh sekolah yang bersangkutan. Kemudian Musfiqon, 2007:19 dalam Tamba dkk., (2015) menjelaskan putus sekolah adalah proses berhentinya siswa secara terpaksa dari suatu lembaga pendidikan tempat dia belajar. Artinya adalah terlantarnya anak dari sebuah lembaga pendidikan formal, yang disebabkan oleh berbagai faktor, salah satunya kondisi ekonomi keluarga yang tidak memadai.

Pendidikan merupakan bentuk investasi dalam bentuk modal manusia. Pentingnya modal manusia (human capital) dalam pembangunan dimulai atas dasar pemikiran Theodore Schultz mengenai investment in human capital. Ia memperlihatkan bahwa pendidikan merupakan suatu bentuk investasi dalam pembangunan yang dapat berkontrubusi langsung terhadap pertumbuhan ekonomi suatu negara (Atmanti, 2005). Todaro \& Smith (2006) juga menjelaskan bahwa modal manusia (human capital) adalah istilah yang sering digunakan oleh para ekonom untuk pendidikan, kesehatan, kapasitas manusia yang lain yang dapat meningkatkan produktivitas jika hal-hal tersebut ditingkatkan. Artinya, ketika seseorang ingin meningkatkan produktivitas, ia harus meningkatkan keterampilan dan pengetahuan melalui pendidikan. Selain itu, kesehatan juga berpengaruh terhadap produktivitas karena ketika seseorang ingin mencapai tingkat produktivitas yang tinggi, ia harus berada dalam kondisi kesehatan yang terjaga.

Menurut Becker (1995), modal manusia dapat meningkatkan kesejahteraan ekonomi dan mengurangi kemiskinan. Modal manusia yang diperoleh melalui pendidikan merupakan investasi dan sekaligus menjadi kesempatan untuk berkompetisi mendapatkan penghidupan yang lebih baik di masa mendatang (Ustama, 2009). Semakin tinggi pendidikan, maka hidup manusia akan menjadi semakin berkualitas (Nugroho, 2014). Semakin tinggi kualitas hidup manusia, semakin tinggi pula tingkat kesejahteraan ekonomi, dan tentunya hal ini menjadi instrumen paling efektif untuk memotong mata rantai kemiskinan di suatu negara.

Tingkat pendidikan yang dimiliki seseorang juga ditentukan oleh perpaduan antara kekuatan permintaan dan penawaran 
seperti barang ekonomi. Namun, yang paling berpengaruh terhadap pendidikan adalah sisi permintaanya di mana tingkat pendidikan seseorang menjadi faktor penentu dalam memperoleh pekerjaan di sektor modern. Semakin tinggi pendidikan yang dicapai seseorang, pekerjaan dan penghasilan yang diperoleh akan semakin baik.

Adapun beberapa variabel yang sangat mempengaruhi tingkat permintaan terhadap pendidikan, seperti pengaruh budaya, gender, status sosial, pendidikan orang tua, dan besarnya anggota keluarga. Persepsi orang tua dalam hal pendidikan juga dapat mempengaruhi permintaan pendidikan (Chattopadhyay, 2012). Apabila persepsi orang tua positif terhadap pendidikan, tentunya dapat menjadikan anak lebih termovitasi dalam belajar dan meningkatkan pendidikannya sampai ke tingkat tertinggi. Begitu pula sebaliknya, apabila persepsi orang tua negatif terhadap pendidikan, hal tersebut akan menjadikan anak kurang termotivasi dalam belajar, dan bahkan bisa menyebabkan anak putus sekolah dan/ tidak melanjutkan sekolah (Solina, 2017).

Selain itu, pencapaian siswa tidak hanya dipengaruhi oleh modal manusia yang mereka miliki tetapi juga dipengaruhi dari bagaimana mereka berinteraksi dengan lingkungan mereka sebagai makhluk sosial (Teachman et al., 1997). Dalam hal ini, Teachman menyebutkan teori modal sosial Coleman berkontribusi pada pendekatan teoritis untuk mengidentifikasi faktor keluarga sebagai faktor tambahan yang mempengaruhi sekolah.

Menurut Coleman (1988) dampak keluarga pada prestasi siswa di sekolah dapat dibedakan menjadi tiga komponen. Komponen yang pertama adalah keuangan modal. Keuangan modal disini bisa diukur dengan pendapatan keluarga. Kemudian komponen yang kedua adalah modal manusia dimana dalam komponen ini, modal manusia diukur dengan pendidikan orang tua. Dan komponen yang ketiga adalah modal sosial yang mengacu pada nilai jaringan sosial dan interaksi sosial.

Di tingkat keluarga, modal sosial mencerminkan sifat hubungan yang ada di antara anggota keluarga (orang tua dan anak). Sedangkan di tingkat masyarakat, modal sosial berada pada norma, jejaring sosial, dan interaksi yang mendukung pencapaian pendidikan seperti teman pergaulan. Oleh karena itu, modal sosial mempunyai peran penting dalam mendorong anak untuk mencapai pendidikan dan mendapatkan modal manusia yang tinggi.

Teori pushout dan pullout merupakan teori yang dapat menjelaskan alasan siswa putus sekolah. Teori pushout mengatakan bahwa terdapat beberapa faktor dari dalam sekolah yang mendorong siswa untuk keluar sekolah seperti lingkungan dan kebijakan sekolah. Tate (2008) menyebutkan bahwa bullying dan pelecehan di sekolah juga mendorong siswa untuk keluar. Hal ini dapat disimpulkan bahwa pushout merupakan siswa yang sukarela meninggalkan sekolah karena tidak adanya dukungan yang memadai dari sekolah.

Sedangkan teori pullout mengatakan bahwa ada faktor dari luar sekolah yang mempengaruhi siswa putus sekolah yaitu berupa peluang kerja. Permintaan di pasar tenaga kerja dengan keterampilan rendah dan 
upah yang rendah menyebabkan siswa keluar dari sekolahnya (Mcneal, 1997). Dalam hal ini, teori pushout dan pullout sangat berkaitan dengan permintaan pendidikan.

\section{METODE}

Jenis penelitian ini adalah penelitian kuantitatif yang merupakan penelitian yang menekankan pada pengujian teori-teori melalui pengukuran variabel-variabel penelitian dengan angka dan melakukan analisis data dengan prosedur statistik (Indriantoro and Supomo, 2016). Sedangkan desain pada penelitian ini adalah menganalisis berbagai faktor yang menyebabkan terjadinya putus sekolah menengah pertama dan bagaimana peran BOS bagi anak putus sekolah di Kabupaten Purworejo. Data yang digunakan untuk analisis penelitian ini bersumber dari data primer. Data primer yang digunakan dalam penelitian ini adalah dengan melakukan penyebaran kuesioner kepada mantan siswa Sekolah Menengah Pertama yang terdiri dari siswa putus sekolah dan siswa lulusan sekolah tingkat Sekolah Menengah Pertama. Populasi yang digunakan dalam penelitian ini adalah selama 3 tahun terakhir yaitu pada tahun ajaran 2015/2016 sampai dengan tahun ajaran 2017/2018 yang peneliti dapatkan dari Dinas Pendidikan Kepemudaan dan Olahraga Kabupaten Purworejo. Di mana data tersebut terdiri dari siswa putus sekolah dan siswa lulusan Sekolah Menengah Pertama sebanyak $\mathbf{2 5 . 1 6 2}$ siswa. Kemudian, untuk mengetahui besarnya ukuran sampel dalam penelitian ini digunakan rumus Slovin sebagai berikut:

$$
\mathrm{n}=\frac{N}{1+N e^{2}}
$$

Keterangan: $\mathrm{n}=$ Jumlah sampel

$\mathrm{N}$ = Ukuran populasi

$\mathrm{e}^{2}=$ Persentase kesalahan pengambilan sampel

Dalam penelitian ini menggunakan standar eror $10 \%$ dan dari populasi di atas dapat dihitung sebagai berikut:

$$
\begin{aligned}
& \mathrm{n}=\frac{25.162}{1+25.162 \times 0,1^{2}}=\frac{25.162}{1+25.161 \times 0,01^{2}}=\frac{25.162}{251,63} \\
& \mathrm{n}=99,99 \text { dibulatkan menjadi } 100
\end{aligned}
$$

dari hasil perhitungan diatas maka, jumlah sampel yang diambil sebesar 100 dengan proporsi putus sekolah sebanyak 30 siswa dan lulusan SMP sebanyak 70 siswa. Teknik pengambilan sampel yang digunakan dalam penelitian ini adalah teknik non-probabilitas dengan pendekatan Convenience Sampling. Convenience Sampling merupakan metode pemilihan sampel dari elemen populasi yang datanya mudah diperoleh peneliti (Indriantoro and Supomo, 2016). Penelitian ini menggunakan teknik Convenience Sampling karena adanya kendala di lapangan seperti sekolah yang menutupi keberadaan siswa putus sekolah. Oleh karena itu, sampel yang digunakan dalam penelitian ini hanya dari beberapa sekolah yang bersedia memberikan data siswa putus sekolah, seperti pada tabel 5

\begin{tabular}{|c|c|c|}
\hline No. & Nama Sekolah Swasta & Sampel \\
\hline 1. & Muhammadiyah & 5 \\
\hline 2. & SMP Sultan Agung Purworejo & 2 \\
\hline 3. & SMP Bhakti Karya Bener & 2 \\
\hline 4. & SMP Barata Bener & 3 \\
\hline 5. & SMP Islam Sudirman Bruno & 9 \\
\hline 6. & SMP Panca Marga Bhakti & 4 \\
\hline 7. & SMP PGRI Bruno & 4 \\
\hline 8. & Terpadu & 1 \\
\hline \multicolumn{2}{|c|}{ TOTAL } & 30 \\
\hline
\end{tabular}
dan tabel 6.Tabel

\section{Jumlah Sampel Anak Putus Sekolah}


Model yang digunakan dalam penelitian ini adalah regresi model logit yang merupakan bagian dari analisis regresi yang digunakan ketika variabel dependen merupakan variabel dummy atau terdiri dari dua nilai dan variabel yang digunakan dalam penelitian bersifat primer. Metode ini diolah dengan menggunakan program Stata 14 untuk membantu dalam menganalisis variabelvariabel.

Tabel 6. Jumlah Sampel Lulusan Sekolah

\begin{tabular}{lll}
\hline No. & Nama SMP Swasta & Sampel \\
\hline 1. & SMP Muhammadiyah & 10 \\
2. & SMP Islam Sudirman & 13 \\
3. & SMP PGRI Bruno & 9 \\
4. & SMP Terpadu Ash- & 15 \\
5. & SMP Bhakti Karya Bener & 10 \\
6. & SMP Barata Bener & 8 \\
7. & SMP Panca Marga Bhakti 1 & 5 \\
TOTAL & 70 \\
\hline
\end{tabular}

Dalam penelitian ini maka regresi model logit ditulis sebagai berikut:

$\mathrm{L}_{\mathrm{i}}=\operatorname{In}[\mathrm{Pi1}-\mathrm{Pi}]=\beta_{\mathrm{o}}+\beta_{1} \mathrm{I}_{\mathrm{i}}+\beta_{2} \mathrm{~F}_{\mathrm{i}}+\beta_{3} \mathrm{~S}_{\mathrm{i}}+$ $\beta_{4} \mathrm{P}_{\mathrm{i}}+\mathrm{u}_{\mathrm{i}}$

\section{Keterangan:}

$\mathrm{L}_{\mathrm{i}}=1$ jika putus sekolah, o jika tidak putus sekolah (variabel dependen)

$\beta_{\mathrm{o}}, \beta_{1}, \beta_{3}, \beta_{4}=$ Koefisien parameter

$\mathrm{I}_{\mathrm{i}} \quad=$ Karakteristik Individu

$\mathrm{F}_{\mathrm{i}} \quad=$ Karakteristik Keluarga

$\mathrm{S}_{\mathrm{i}} \quad=$ Karakteristik Sekolah

$\mathrm{P}_{\mathrm{i}} \quad=$ Kebijakan Pemerintah

Variabel karakteristik individu

meliputi persepsi pendidikan dan kesehatan. Variabel karakteristik keluarga (F) meliputi jumlah saudara, saudara kandung putus sekolah, waktu membantu orang tua, dan dukungan akademik orang tua. Variabel karakteristik sekolah (S) meliputi masalah dengan guru, masalah dengan teman sekolah, jarak, dan teman yang putus sekolah. Kebijakan pemerintah (P) yaitu BOS.

Uji statistik yang digunakan diantaranya adalah (1) Uji Signifikasi Keseluruhan Model yang terdiri dari Uji Wald dan Likelihood Ratio (LR). (2) Uji Goodness Of Fit (GOF) yang digunakan untuk menilai apakah nilai prediksi yang diperoleh model tepat dalam mencerminkan nilai-nilai yang diamati pada data yang di ambil (Hosmer et all., 1991). Uji GOF terdiri dari Mc Fadden $R^{2}$, Pearson Goodness Of Fit, Hosmer-Lemeshow goodness of fit, Klasifikasi Tabel (Classification Table), Receiver Operating Characteristic (ROC), dan Linktest. kemudian ntrepretasi hasil regresi logit menggunakan Average Marginal Effect.

\section{HASIL DAN PEMBAHASAN}

Pendidikan merupakan peran yang sangat penting sekaligus sebagai pendukung dalam proses pembangunan suatu bangsa. Dengan adanya pendidikan, kualitas dan sumber daya manusia akan semakin meningkat sehingga bekal yang diberikan seperti pengetahuan, kemampuan, dan sikap dapat dikembangkan di masyarakat yang membutuhkan sebagai bentuk partisipasi seseorang dalam pembangunan nasional.

Namun, permasalahan pendidikan seperti fenomena putus sekolah yang terjadi di Kabupaten Purworejo mengakibatkan terhambatnya upaya dalam meningkatkan kualitas sumber daya manusia. Selain itu, masalah tersebut juga akan menghadirkan masalah baru seperti meningkatnya angka pengangguran, rendahnya kesejahteraan sosial, 
dan meningkatnya angka kriminalitas persepsi buruk pendidikan memiliki nilai khususnya dari anak yang tidak signifikansi sebesar 0,024 lebih kecil dari taraf berpendidikan.

Variabel penelitian dimulai dari signifikan 0,05. Hal tersebut dapat diartikan pendidikan dan kesehatan. Hasil analisis bahwa variabel persepsi buruk pendidikan berpengaruh siginifikan secara statistik regresi logit menunjukkan bahwa variabel terhadap keputusan anak untuk putus sekolah.

Tabel 7. berikut adalah hasil regresi model logitTabel 7. Hasil Regresi Model Logit

\begin{tabular}{|c|c|c|c|c|}
\hline \multirow{2}{*}{ Variabel } & \multicolumn{4}{|c|}{ Koefisien Parameter } \\
\hline & Koefisien & Std. Err. & $\mathrm{P}>|\mathrm{Z}|$ & $\mathrm{Z}$ \\
\hline \multicolumn{5}{|l|}{ Karakteristik Individu } \\
\hline Persepsi pendidikan & 2,089744 & 0,9254738 & 0,024 & 2,26 \\
\hline Kesehatan & & o,8757468 & 0,016 & 2,42 \\
\hline \multicolumn{5}{|l|}{ Karakteristik Keluarga } \\
\hline Jumlah saudara & 1,283324 & 0,436115 & 0,003 & 2,94 \\
\hline Saudara putus sekolah & 4,135089 & 1,069542 & 0.000 & 3,87 \\
\hline Membantu orang tua & $-2,859805$ & 1,090486 & 0,009 & $-2,62$ \\
\hline $\begin{array}{l}\text { Dukungan akademik dari orang tua } \\
\text { Karakteristik Sekolah }\end{array}$ & \multicolumn{3}{|c|}{ Karakteristik Sekolah } & $-2,31$ \\
\hline Masalah guru & 2,15331 & 1,202151 & 0,073 & 1,79 \\
\hline Masalah teman & $-1,051351$ & 0,8268252 & 0,204 & $-1,27$ \\
\hline Jarak & $-0,1069554$ & 0,5625681 & 0,849 & $-0,19$ \\
\hline Teman putus sekolah & 2,542511 & 1,28704 & 0,048 & 1,98 \\
\hline \multicolumn{5}{|l|}{ Kebijakan Pemerintah } \\
\hline Peran BOS & 0,6085339 & 0,4171375 & 0,145 & 1,46 \\
\hline Konstanta & $-11,85136$ & 4,798389 & 0,014 & $-2,47$ \\
\hline Likehood Ratio & \multicolumn{4}{|c|}{$76,25(p-$ value $=0.0000)$} \\
\hline Wald $\chi^{2}$ & \multicolumn{4}{|c|}{$60,87(p-v a l u e=0.0000)$} \\
\hline McFadden's R ${ }^{2}$ & \multicolumn{4}{|l|}{0,6242} \\
\hline \multicolumn{5}{|l|}{ Linktest } \\
\hline _hat & 1,018905 & 0,2547715 & 0.000 & 4,00 \\
\hline _hatsq & 0,0139428 & 0,0811557 & 0,864 & 0,17 \\
\hline Pearson chi2 (86) & \multicolumn{4}{|c|}{$51,05(p$-value $=0,9990)$} \\
\hline Hosmer-Lemeshow chi2 (8) & \multicolumn{4}{|c|}{$2,38(p$-value $=0,9672)$} \\
\hline $\mathrm{ROC}$ & \multicolumn{4}{|l|}{0,9567} \\
\hline Classification Tabel & \multicolumn{4}{|l|}{$89,00 \%$} \\
\hline
\end{tabular}

Sumber: Hasil output Stata $14{ }^{* *} \alpha=0,05$

Berdasarkan hasil penelitian, semakin anak berpikir bahwa sekolah hanya membuang-buang waktu, motivasi belajar seorang anak akan berkurang sehingga dapat meningkatkan peluang untuk putus sekolah sebesar 14,7\%. Anak yang menganggap bahwa sekolah hanya membuang-waktu disebabkan karena kurangnya kesadaran dari diri sendiri dan orang tua akan investasi pendidikan di masa depan sehingga berdampak pada 
rendahnya minat anak untuk belajar dan motivasi untuk terus menempuh pendidikan. Hal tersebut sesuai dengan teori permintaan pendidikan. Menurut Chattopadhyay (2012), permintaan pendidikan tidak hanya dipengaruhi oleh persepsi anak saja, melainkan persepsi dari orang tua. Permintaan pendidikan akan meningkat apabila anak dan orang tua percaya bahwa pendidikan yang tinggi dapat dijadikan investasi dalam meningkatkan penghasilan di masa mendatang. Orang tua yang memiliki persepsi baik tentang pendidikan akan menumbuhkan rasa tanggung jawab yang besar terhadap pendidikan anak sehingga mereka mau mengorbankan sebagian hartanya agar dapat menyekolahkan anaknya sampai ke jenjang pendidikan tertinggi. Sebaliknya, apabila orang tua memiliki persepsi buruk terhadap pendidikan maka tidak akan ada dorongan dari orang tua kepada anaknya untuk tetap bersekolah sehingga menjadikan anak kurang termotivasi dalam belajar.

Kemudian variabel selanjutnya adalah kesehatan. Hasil analisis regresi logit menunjukkan bahwa variabel kesehatan memiliki nilai signifikansi sebesar o,o16 lebih kecil dari taraf signifikan 0,05. Artinya, variabel kesehatan berpengaruh siginifikan secara statistik terhadap keputusan anak untuk putus sekolah.

Hal tersebut sesuai dengan teori modal manusia (human capital) karena pemeliharaan kesehatan merupakan bentuk investasi dalam human capital (Atmanti, 2005). Apabila seseorang berada dalam kondisi kesehatan yang baik, maka ia akan mampu meningkatkan keterampilan dan pengetahuan melalui pendidikan dan dapat dijadikan bekal untuk meningkatkan produktivitas yang dapat menciptakan nilai tambah. Sebaliknya, apabila seorang anak memiliki kondisi kesehatan yang buruk, maka mau tidak mau anak tersebut harus absen atau tidak masuk sekolah sehingga kegiatan belajar di sekolah menjadi terganggu. Hasil penelitian menunjukkan bahwa kesehatan yang buruk akan meningkatkan peluang untuk putus sekolah sebesar 14,9\%. Kondisi kesehatan yang tidak memungkinkan untuk sekolah mengharuskan mereka untuk absen dan apabila sudah terlalu banyak absen akhirnya mereka memutuskan untuk berhenti sekolah. Padahal sebenarnya masih ada keinginan dari anak untuk kembali melanjutkan sekolah, tetapi karena kondisi kesehatan tidak memungkinkan menyebabkan anak tersebut mengurungkan niatnya untuk kembali bersekolah.

Variabel kedua yaitu karakteristik keluarga berupa jumlah saudara, saudara kandung putus sekolah, membantu orang tua, dan dukungan akademik orang tua. Berdasarkan hasil regresi logit, variabel jumlah saudara memiliki nilai signifikansi o,oo3 lebih kecil dari taraf signifikan 0,05. Hasil tersebut dapat diartikan bahwa variabel jumlah saudara berpengaruh signifikan terhadap keputusan anak untuk putus sekolah.

Menurut Todaro \& Smith (2006), jumlah anggota keluarga merupakan salah satu faktor non-ekonomi yang berpengaruh terhadap permintaan pendidikan. Hasil penelitian ini sesuai dengan penelitian Kharisma (2013) yang mengatakan bahwa semakin banyak jumlah saudara maka beban tanggungan orang tua dalam menyekolahkan anak-anaknya semakin banyak sehingga peluang untuk putus sekolah semakin besar. Temuan di lapangan 
menunjukkan setiap bertambahnya anggota keluarga akan mengingkatkan peluang untuk putus sekolah sebesar 9\%. Selain itu, penelitian ini juga mendukung penelitian Cameron (2009) yang mengatakan bahwa banyaknya jumlah keluarga mengakibatkan kepala keluarga menjadi sibuk untuk mencukupi keperluan keluarga dan juga menyebabkan kurangnya perhatian orang tua terhadap pendidikan anak-anaknya sehingga menimbulkan kerentanan terhadap tingkat putus sekolah.

Variabel saudara kandung putus sekolah berpengaruh signifikan terhadap keputusan anak untuk putus sekolah. Hal tersebut dapat dilihat dari hasil model regresi logit yang menujukkan nilai signifikansi o,ooo lebih kecil dari taraf signifikan 0,05. Temuan di lapangan menunjukkan bahwa dari 30 responden putus sekolah, 56\% diantaranya mempunyai saudara kandung yang juga mengalami putus sekolah dan semakin banyak saudara kandung yang putus sekolah dapat meningkatkan peluang untuk putus sekolah sebesar 29,1\%. Hasil ini sesuai dengan penelitian Setyadharma (2015) yang mengatakan bahwa kehadiran saudara kandung yang putus sekolah kemungkinan memberikan peran yang dapat mendorong saudara kandung lainnya untuk meninggalkan sekolah juga. Hal ini dapat disimpulkan bahwa keberhasilan pendidikan saudara kandung mencerminkan keberhasilan pendidikan bagi saudara lainnya, sehingga sangat diperlukan lingkungan keluarga yang baik supaya dapat membawa pengaruh yang baik pula untuk keberhasilan pendidikan anak.

Selanjutnya, hasil regresi logit variabel membantu orang tua menujukkan nilai signifikansi sebesar o,oog lebih kecil dari taraf signifikan 0,05. Hasil ini dapat diartikan bahwa variabel membantu orang tua berpengaruh signifikan terhadap keputusan anak untuk putus sekolah. Banyaknya waktu yang dikorbankan anak untuk membantu pekerjaan rumah atau membantu orang tua mencari nafkah mengakibatkan berkurangnya waktu belajar anak dan fokus sekolah sehingga memungkinkan terjadinya putus sekolah sebesar 20,1\%. Hasil ini mendukung penelitian Hikmah dkk., (2016) yang mengatakan bahwa faktor dominan yang menyebabkan anak putus sekolah adalah membantu orang tua dalam mencari uang dan mengurus rumah tangga. Di kalangan keluarga yang tidak mampu, anak bermotivasi untuk membantu orang tua karena kondisi kebutuhan semakin meningkat dari yang awalnya hanya mencukupi kebutuhan dasar, namun sekarang ditambah dengan adanya kebutuhan lain yang terkadang mau tidak mau kebutuhan tersebut harus dipenuhi. Temuan di lapangan juga menunjukkan bahwa beberapa anak memilih untuk putus sekolah dan membantu orang tua karena kondisi ekonomi yang buruk dan sejak kecil sudah dibiasakan untuk membantu orang tua dalam mencari uang dan juga membantu pekerjaan rumah.

Variabel dukungan akademik orang tua berpengaruh signifikan terhadap keputusan putus sekolah. Hal tersebut dapat dilihat dari hasil regresi model logit yang menunjukkan nilai taraf signifikansi o,o21 lebih kecil dari taraf signifkan 0,05. Hasil ini berkaitan dengan teori modal sosial yang telah dibahas pada bab 2 bahwa dukungan akademik orang tua merupakan salah satu bentuk modal sosial berupa interaksi antara anak dan orang tua yang dapat mempengaruhi sekolah. Perhatian positif yang diberikan orang tua kepada anak sangatlah penting untuk mencapai dan 
mendapatkan modal manusia yang tinggi. Temuan ini juga sesuai dengan penelitian Dewi dkk., (2014) yang menunjukkan bahwa perhatian orang tua mempunyai pengaruh yang besar terhadap keputusan anak untuk putus sekolah. Perhatian orang tua yang dapat menurunkan peluang anak untuk putus sekolah sebesar $15,6 \%$. Maka dari itu, semangat atau dorongan dari orang tua dan dukungan dalam bentuk finansial sangat diperlukan anak dalam memenuhi segala kebutuhan pendidikan. Selain itu, keterlibatan orang tua dalam pendidikan anak seperti membantu mengerjakan pekerjaan rumah juga diperlukan supaya anak menjadi lebih semangat dalam belajar.

Variabel ketiga adalah karakteristik sekolah berupa masalah dengan guru, masalah dengan teman, jarak, dan teman putus sekolah. Hasil regresi logit menunjukkan bahwa variabel masalah dengan guru memiliki nilai signifikansi o,o73 lebih besar dari taraf signifikan 0,05. Hal tersebut dapat diartikan bahwa variabel masalah dengan guru tidak berpengaruh signifikan secara statistik terhadap keputusan putus sekolah. Selain itu, hasil regresi logit juga menunjukkan bahwa variabel masalah dengan teman tidak berpengaruh signifikan secara statistik terhadap keputusan putus sekolah karena memiliki nilai signifikansi o,204 lebih besar dari taraf signfikan o,05. Hasil ini tidak sejalan dengan penelitian Bergeron et al., (2011) yang mengatakan bahwa hubungan negatif dengan guru menjadi predikat terkuat dari keinginan untuk putus sekolah bagi sebagian besar siswa. Berdasarkan temuan di lapangan, hal ini dikarenakan sebagian besar siswa mempunyai dan/ mampu menjalin hubungan baik dengan guru dan temannya di sekolah, sehingga dapat menciptakan suasana nyaman saat berada di sekolah dan dapat menghindari kemungkinan anak untuk putus sekolah. Banyaknya masalah yang dimiliki anak dengan guru memberikan efek sebesar 15,1\% untuk putus sekolah. Kemudian, banyaknya masalah dengan teman di sekolah juga mempengaruhi anak untuk putus sekolah sebesar 7,4\%. Maka dari itu, hubungan baik antara siswa dengan guru dan teman ketika berada di sekolah sangat peting dan juga merupakan salah satu bentuk sikap untuk menghindari adanya bullying yang dapat mendorong terjadinya putus sekolah.

Kemudian variabel jarak juga tidak berpengaruh signifikan secara statistik terhadap keputusan putus sekolah. Hal tersebut dapat dilihat dari hasil regresi logit yang menunjukkan nilai signifikansi variabel jarak o,849 lebih besar dari taraf signifikan 0,05. Hasil ini sesuai dengan penelitian Arizona (2013) yang mengatakan bahwa jarak tidak berpengaruh signifikan karena adanya pemilihan sekolah yang tidak terpaku pada jarak. Selain itu, tersedianya transportasi yang memadai juga telah memudahkan masyarakat khususnya anak sekolah untuk mengakses pendidikan. Temuan di lapangan menunjukkan bahwa keterlibatan orang tua dalam mengantarkan anaknya ke sekolah juga merupakan suatu hal yang penting karena dapat menumbuhkan semangat anak untuk bersekolah sehingga anak tidak cemas atau khawatir terhadap sesuatu yang akan terjadi apabila mereka berangkat sendiri ke sekolah.

$$
\text { Variabel teman putus sekolah }
$$
berpengaruh signifikan secara statistik terhadap keputusan anak putus sekolah. Hal tersebut dapat dilihat dari hasil regresi logit 
yang menunjukkan bahwa variabel teman putus sekolah memiliki nilai signifikansi 0,048 lebih kecil dari taraf signifikan o,o5.

Hasil penelitian ini sesuai dengan penelitian Zaenuri dkk., (2014) yang mengatakan bahwa lingkungan berupa pergaulan dengan teman putus dan/ tidak sekolah sangat berpengaruh terhadap keputusan putus sekolah. Artinya, apabila anak berada di lingkungan pergaulan yang tidak mendukung seperti banyaknya teman bermain yang juga mengalami putus sekolah, maka akan mengakibatkan anak tidak berpikir panjang untuk memutuskan berhenti sekolah seperti teman-temannya. Temuan di lapangan juga menunjukkan bahwa $77 \%$ responden memiliki teman bermain yang juga mengalami putus sekolah dan tidak melanjutkan sekolah lagi karena lebih memilih bekerja guna memenuhi kebutuhannya sendiri. Selain itu, banyaknya teman pergaulan yang putus sekolah memberikan efek kepada anak untuk putus sekolah sebesar 17,9\%.

Variabel terakhir yaitu kebijakan pemerintah berupa program Bantuan Operasional Sekolah (BOS). Berdasarkan hasil regresi logit, variabel kebijakan pemerintah berupa program Bantuan Operasional Sekolah (BOS) menunjukkan nilai signifikansi 0,145 lebih besar dari taraf signifikan o,05. Artinya, variabel kebijakan pemerintah berupa BOS tidak berpengaruh signifikan terhadap keputusan anak untuk putus sekolah.

Hasil ini sesuai dengan penelitian Kharisma (2013) yang mengatakan bahwa bantuan BOS yang diberikan kepada siswa usia 7-15 tahun khususnya tingkat SMP tidak signifikan secara statistik terhadap putus sekolah. Temuan di lapangan menunjukkan bahwa hal ini dikarenakan dana BOS tidak dapat menanggung semua biaya pendidikan sehingga banyak biaya sekolah yang dibebankan kepada orang tua siswa. Lampiran 1 menunjukkan data penerimaan dana BOS jenjang SMP di Kabupaten Purworejo. Pada tahun 2017, penerima dana BOS sebanyak 28.664 siswa mendapatkan bantuan sebesar Rp 679.392 - pertahun sehingga secara rata-rata dana bos yang diterima siswa perbulan hanya sebesar Rp 56.616. Bagi kalangan keluaga yang tidak mampu, tentunya besaran dana BOS tersebut belum bisa dikatakan membantu dalam meringankan beban biaya sekolah. Selain itu, temuan di lapangan juga menunjukkan bahwa kebanyakan orang tua yang anaknya mengalami putus sekolah tidak mengetahui adanya program BOS di sekolah. Sebagian besar dari orang tua merasa bahwa tidak ada kontribusi dari pemerintah yang dapat mengurangi beban orang tua dalam menanggung semua biaya sekolah anak. Kondisi yang seperti ini akan berdampak kepada orang tua miskin karena banyaknya biaya pendidikan anak akan menjadi beban bagi rumah tangga miskin yang dikhawatirkan dapat mempengaruhi untuk putus sekolah. Hasil wawancara dengan beberapa anak putus sekolah menunjukkan bahwa kenyataannya masalah putus sekolah tidak disebabkan karena kondisi ekonomi saja, melainkan adanya faktor kenakalan anak dan adanya motivasi untuk bekerja sehingga sekolah dianggap tidak penting untuk memperbaiki masa depan.

Penelitian mengenai dampak program bantuan pemerintah dalam bidang pendidikan terhadap tingkat putus sekolah dan partisipasi sekolah memilik hasil yang beraneka ragam. Cameron (2009) dalam penelitianya mengatakan bahwa program Jaring Pengaman 
Sosial (JPS) efektif dalam mengurangi putus sekolah pada tingkat SMP, namun tidak memberikan dampak yang signifikan ada tingkat SD dan SMA. Kemudian, Borraz \& González (2009) dalam penelitiannya tentang program transfer tunai bersyarat (conditional cash transfer) menunjukkan bahwa program pemerintah tersebut tidak berdampak pada tingkat pasrtisipasi sekolah dan putus sekolah.

Program Bantuan Operasional Sekolah (BOS) menjadi salah satu bentuk program pemerintah untuk mencegah terjadinya putus sekolah sehingga kualitas sumber daya manusia tetap dapat ditingkatkan. Hasil penelitian juga menunjukkkan semakin banyaknya BOS yang diberikan akan memberikan efek untuk tidak putus sekolah sebesar 4,2\%. Namun, kenyataannya program BOS masih belum efektif dalam mencegah terjadinya putus sekolah di Kabupaten Purworejo. Anak-anak yang mendapatkan BOS masih banyak yang mengalami putus sekolah. Hal ini juga dapat dikarenakan rendahnya minat anak untuk kembali bersekolah karena mereka sudah merasa nyaman dengan pekerjaan yang mereka dapatkan.

Tabel 8 memperlihatkan hasil average marginal effect dari persamaan regresi logit. Pertama adalah karakteristik individu berupa persepsi buruk pendidikan dan kesehatan. Tabel 4.7 menunjukkan bahwa semakin buruk presepsi pendidikan akan meningkatkan probabilitas untuk putus sekolah sebesar 0,1472343. Hasil average marginal effect juga menunjukkan bahwa anak yang memiliki kondisi kesehatan yang buruk akan meningkatkan probabilitas untuk putus sekolah sebesar o,1492579 dibandingkan anak yang memiliki kondisi kesehatan yang baik.
Tabel 8. Average Marginal Effect

\begin{tabular}{c} 
Margins \\
\hline Dydx $\quad P>|Z|$
\end{tabular}

Karakteristik Individu

\begin{tabular}{|c|c|c|}
\hline Persepsi pendidikan & 0,1472343 & 0,012 ** \\
\hline Kesehatan & 0,1492579 & $0,021 * *$ \\
\hline \multicolumn{3}{|l|}{ Karakteristik Keluarga } \\
\hline Jumlah saudara & 0,0904174 & $0,007^{* *}$ \\
\hline Saudara putus sekolah & 0,2913403 & $0.000 * *$ \\
\hline Membantu orang tua & $-0,2014894$ & $0.001 * *$ \\
\hline Dukungan orang tua & $-0,15641$ & $0,012 * *$ \\
\hline \multicolumn{3}{|l|}{ Karakteristik Sekolah } \\
\hline Masalah dengan guru & 0,1517129 & 0,064 \\
\hline Masalah dengan teman & $-0,0740736$ & 0,213 \\
\hline Jarak & $-0,0075356$ & 0,847 \\
\hline Teman putus sekolah & 0,1791342 & $0,038 * *$ \\
\hline \multicolumn{3}{|l|}{ Kabijakan Pemerintah } \\
\hline BOS & 0,0428746 & 0,146 \\
\hline
\end{tabular}

Sumber: Hasil Output Stata; ${ }^{* *} \alpha=0,05$

$\mathrm{o}=$ tidak putus sekolah

$1=$ putus sekolah

Kedua adalah karakteristik keluarga. Hasil average marginal effect menunjukkan bahwa setiap tambahan satu anggota keluarga, akan meningkatkan probabilitas untuk putus sekolah sebesar o,o904174. Kemudian, setiap bertambahnya saudara yang mengalami putus sekolah juga akan meningkatkan probabilitas untuk putus sekolah sebesar 0,2913403. Membantu orang tua dan dukungan orang tua juga mempengaruhi pendididikan seorang anak. Hasil average marginal effect memperlihatkan bahwa semakin banyak waktu yang digunakan anak untuk membantu orang tua akan menurunkan probabilitas untuk tidak putus sekolah sebesar o,2014894. Sedangkan variabel dukungan orang tua menunjukkan bahwa semakin tinggi dukungan dari orang 
tua dalam pendidikan anak, maka akan menurunkan probabilitas untuk putus sekolah sebesar 0,15641.

Ketiga adalah karakteristik sekolah berupa masalah dengan guru, masalah dengan teman, jarak, dan teman putus sekolah. Hasil average marginal effect menunjukkan bahwa semakin banyaknya masalah yang dimiliki anak dengan guru di sekolah akan meningkatkan probabilitas untuk putus sekolah sebesar 0,1517129. Masalah dengan teman di sekolah juga mempengaruhi pendidikan anak. Semakin banyak masalah yang dimiliki anak dengan temannya di sekolah akan menurunkan probabilitas untuk tidak putus sekolah sebesar o,0740736. Kemudian, semakin jauh jarak antara rumah dan lokasi sekolah juga akan menunrunkan probabilitas untuk tidak putus sekolah sebesar o,0075356. Selanjutnya adalah keberadaan teman putus sekolah di lingkungan pergaulan. Hal tersebut dapat dilihat dari hasil average marginal effect yang menunjukkan bahwa semakin bertambahnya teman yang putus sekolah di lingkungan bermain maka akan meningkatkan probabilitas anak untuk putus sekolah sebesar 0,1791342.

Yang terakhir adalah program BOS. Hasil average marginal effect menunjukkan bahwa semakin banyak BOS yang diberikan kepada siswa maka akan meningkatkan probabilitas untuk tidak putus sekolah sebesar o,0428746.

\section{SIMPULAN}

Berdasarkan hasil analisis data dan pembahasan dari penelitian ini, maka simpulan dari penelitian ini adalah sebagai berikut: (1) Karakteristik individu berupa persepsi buruk tentang pendidikan berpengaruh positif dan siginifikan secara statistik karena semakin anak berpikir bahwa sekolah hanya membuang-buang waktu, maka motivasi belajar seorang anak akan berkurang sehingga dapat meningkatkan peluang untuk putus sekolah. Kesehatan berpengaruh positif dan signifikan terhadap keputusan putus sekolah karena kesehatan yang baik/buruk dapat berdampak pada aktivitas anak untuk sekolah. (2) Karakteristik keluarga berupa jumlah saudara berpengaruh positif dan signifikan terhadap keputusan putus sekolah karena semakin banyak jumlah saudara maka beban tanggungan orang tua dalam menyekolahkan anak-anaknya semakin banyak sehingga peluang untuk putus sekolah semakin besar. Saudara putus sekolah berpengaruh positif dan signifikan terhadap keputusan anak putus sekolah karena kehadiran saudara kandung yang putus sekolah kemungkinan memberikan panutan yang dapat mendorong saudara kandung lainnya untuk meninggalkan sekolah juga. Membantu orang tua berpengaruh signifikan terhadap keputusan putus sekolah karena banyaknya waktu yang dikorbankan anak untuk membantu pekerjaan rumah atau membantu orang tua mencari nafkah mengakibatkan berkurangnya waktu belajar dan fokus sekolah sehingga memungkinkan terjadinya putus sekolah. Dukungan akademik orang tua berpengaruh signifikan terhadap keputusan putus sekolah karena dukungan orang tua dapat meningkatkan semangat anak untuk berseskolah. (3) Karakteristik sekolah berupa masalah dengan guru dan masalah dengan teman tidak berpengaruh signifikan karena terjalinnya hubungan baik antara anak dengan guru dan teman di sekolah, sehingga dapat menciptakan suasana nyaman saat anak berada di sekolah. Jarak tidak berpengaruh 
signifikan karena adanya pemilihan sekolah yang tidak terpaku pada jarak. Selain itu, teman putus sekolah memiliki hubungan positif dan signifikan secara statistik terhadap keputusan anak putus sekolah karena lingkungan berupa pergaulan dengan teman putus dan/ tidak sekolah sangat perpengaruh terhadap keputusan putus sekolah. (4) Kebijakan pemerintah berupa Bantuan Operasional Sekolah tidak berpengaruh signifikan terhadap keputusan anak putus sekolah. Hal ini dikarenakan, BOS telah disalurkan kepada seluruh siswa namun masih terdapat anak yang mengalami putus sekolah. Selain itu, dana BOS tidak dapat menutup semua biaya operasional sekolah sehingga banyak biaya sekolah yang dibebankan kepada orang tua siswa serta terdapatnya faktor lain yang menyebabkan keputusan anak untuk putus sekolah yaitu faktor kenakalan anak dan adanya motivasi untuk bekerja sehingga sekolah dianggap tidak penting untuk memperbaiki masa depan.

Berdasarkan kesimpulan yang di paparkan di atas, maka saran yang diberikan adalah: (1) Sebagai lingkungan yang membawa pengaruh besar untuk anak, diharapkan orang tua dapat memberikan pengetahuan sejak dini kepada anak mengenai pentingnya pendidikan untuk masa depan. Hal tersebut akan memberikan kesadaran bagi anak bahwa pendidikan sangat penting untuk masa depan sehingga anak menjadi termotivasi untuk menempuh pendidikan yang tinggi dan tidak ada lagi anggapan bahwa sekolah hanya membuang-buang waktu. (2) Perlu adanya pengawasan orang tua dalam pergaulan anak. Hubungan baik antara orang tua dan anak sangat penting agar dapat menjalin komunikasi yang lebih dekat dan sikap saling keterbukaan. Hal tersebut menjadikan orang tua dapat mengetahui teman-teman yang berada di lingkungan pergaulan anak sehingga dapat mengarahkan dan memastikan bahwa anaknya berada di lingkungan pergaulan yang baik. (3) Pihak sekolah dapat memberikan sosialisasi kepada orang tua mengenai Program Bantuan Operasional Sekolah yang diharapkan dapat mencegah terjadinya anak putus sekolah. Selain itu, pihak sekolah juga diharapkan dapat memberikan bantuan lebih kepada orang tua miskin dalam membiayai pendidikan anak terutama kepada anak yang terancam putus sekolah karena ketidakmapuan ekonomi. (4) Pihak pemerintah diharapkan dapat memaksimalkan bantuan pendidikan lainnya selain BOS yang dapat meningkatkan partisipasi sekolah dan mengurangi tingkat putus sekolah.

\section{DAFTAR PUSTAKA}

Ali, M. (2009) Pendidikan Untuk Pembangunan Nasional. Jakarta: IMTIMA.

Arizona, M. M. (2013) 'Kajian Tentang Siswa Putus Sekolah Pada Tingkat SMA/SMK Di Kabupaten Gresik (Studi Kasus Di Kecamatan Gresik Kabupaten Gresik)', Jurnal Unesa, 2(3), pp. 151-158.

Atmanti, H. D. (2005) 'Investasi Sumber Daya Manusia Melalui Pendidikan', Jurnal Dinamika Pembangunan, 2(1), pp. 30-39.

Badan Pusat Statistik (2018) Potret Pendidikan Indonesia (Statistik Pendidikan Indonesia 2018). Jakarta.

Becker, G. S. (1995) Human Capital and Poverty Alleviation, Journal of Human Resources Development and Operations Policy.

Bergeron, J., Chouinard, R. and Janosz, M. (2011) 'The Impact of Teacher-Student Relationships and Achievement Motivation on Students ' Intentions to Dropout According to Socio-economic Status', US-China Education Review, 2, pp. 273-279.

Borraz, F. and González, N. (2009) 'Impact of the uruguayan conditional cash transfer program', 
Cuadernos de Economia - Latin American Journal of Economics, 46(134), pp. 243-271. doi: 10.4067/So717-68212009000200006.

Cameron, L. (2009) 'Can a public scholarship program successfully reduce school drop-outs in a time of economic crisis? Evidence from Indonesia', Economics of Education Review, 28(3), pp. 308-317. doi: 10.1016/j.econedurev.2007.09.013.

Chattopadhyay, S. (2012) Education and Economics: Disciplinary Evolution and Policy Discourse. New Delhi, India: Oxford University Press.

Coleman, J. S. (1988) 'Social Capital in the Creation of Human Capital', American Journal of Sociology, 94, pp. S95-S120. doi: 10.1086/228943.

Dewi, N. A. K., Zukhri, A. and Dunia, I. K. (2014) 'Analisis Faktor-Faktor Penyebab Anak Putus Sekolah 2012 / 2013', 4(1).

Granado, F. J. A. del et al. (2007) Investing in Indonesia 'S Education, Policy Research.

Hikmah, L., Quraisy, H. and Arifin, J. (2016) 'Kemiskinan dan Putus Sekolah', Equilibrium pendidikan sosiologi, IV(2), pp. 164-173. doi: 10.1002/hlca.19770600336.

Hosmer, D. W., Taber, S. and Lemeshow, S. (1991) 'The importance of assessing the fit of logistic regression models: A case study', American Journal of Public Health, 81(12), pp. 1630-1635. doi: 10.2105/AJPH.81.12.1630.

Indriantoro, N. and Supomo, B. (2016) Metodologi Penelitian Bisnis. Pertama. Yogyakarta: BPFE Yogyakarta.

Kamsihyati, T., Sutomo and FS, S. (2016) 'Kajian FaktorFaktor Penyebab Anak Putus Sekolah di Desa Jangrana Kecamatan Kesugihan Kabupaten Cilacap ( Study on', Geo Edukasi, 5(1), pp. 16-21.

Kharisma, B. (2013) 'Dampak Program Bantuan Operasional Sekolah ( BOS ) Terhadap Tingkat Putus Sekolah di Indonesia: Analisis DID The Impact Of The School Operational Assistance ( BOS ) Program On The Dropout Rate In Indonesia: A DID Analysis', Jurnal Ekonomi Kuantitatif Terapan, 6(1), pp. 7-15.

Mcneal, R. B. (1997) 'Are Students Being Pulled Out of High School? The Effect of Adolescent Employment on Dropping Out Author ( s ): Ralph B . McNeal , Jr. Published by: American
Sociological Association Stable URL : http://www.jstor.org/stable/2673209 Are Students Being P', American Sociological Association, 70(3), pp. 206-220.

Mudyaharjo (2001) Pengantar Pendidikan. Sebuah. Studi Awal Tentang Dasar-Dasar Pendidikan Pada Umumnya dan Pendidikan Indonesia. Jakarta: PT. Raja Grafindo Persada.

Nugroho (2014) 'Pengaruh Pendidikan Terhadap Pertumbuhan Ekonomi', Jurnal Media Ekonomi dan Manajemen, 29(2), pp. 195-202.

Setyadharma, A. (2015) 'Upper secondary school dropout: lessons from central java province, indonesia', in Research and Community Service Institute Semarang State University, pp. 303-313. Available at:

http://conf.unnes.ac.id/index.php/uicric/uicric2o1 5 .

Solina, W. (2017) 'Persepsi Orangtua tentang Pendidikan', Konselor, 6(3), p. 91. doi: 10.24036/02017637691-ooo.

Tamba, E. M., Krisnani, H. and Gutama, A. S. (2015) 'Pelayanan Sosial Bagi Remaja Putus Sekolah', Social Work Journal, 4(2), pp. 218-222. doi: 10.24198/share.v4i2.13077.

Tate, D. (2008) The schools for all campaign: The school bias $\mathcal{E}$ pushout problem. San Fransisco, CA: American Civil Liberties Union of Northern California.

Teachman, J. D., Paasch, K. and Carver, K. (1997) 'Social Capital and the Production of Human Capital', Journal of Social Forces, 75(4), pp. 1-30.

Todaro, M. P. and Smith, S. C. (2006) Pembangunan Ekonomi. Kesembilan. Jakarta: Erlangga.

Ustama, D. D. (2009) 'Peranan Pendidikan Dalam Pengentasan Kemiskinan', Jurnal Ilmu Administrasi dan Kebijakan Publik, 6(1), pp. 1-12.

Witte, K. and Rogge, N. (2013) 'Dropout from Secondary Education: All's well that begins well', European Journal of Education, 48(1), pp. 131-149. doi: 10.1111/ejed.12001.

Zaenuri, M., Matsum, J. and Thomas, Y. (2014) 'Tingkat,Pendapatan Sosial Budaya dan Jarak Rumah dengan sekolah sebagai faktor penyebab anak putus sekolah di SMPN', Jurnal Untan, pp. 115 . 